\title{
PERSEPSI MAHASISWA DAN DOSEN PENASEHAT AKADEMIK TENTANG TUGAS PENASEHAT AKADEMIK DI JURUSAN TEKNIK SIPIL UNIVERSITAS NEGERI JAKARTA
}

\author{
Vian Rahmawati ${ }^{1}$, Santoso Sri Handoyo ${ }^{2 *}$, Dadang Suyadi $\mathbf{S}^{3}$ \\ ${ }^{1}$ Alumni Pendidikan Teknik Bangunan FT UNJ,Jakarta, Indonesia. \\ 2 Pendidikan Teknik Bangunan, FT UNJ, Jakarta, Indonesia. \\ ${ }^{3}$ Pendidikan Teknik Bangunan, FT UNJ, Jakarta, Indonesia \\ *Corresponding author: santoso_handoyo@unj.ac.id
}

\begin{abstract}
The objectives of this study to determine the perception of students and faculty Academic Advisor on Academic Advisory assignments in the Department of Civil Engineering, State University of Jakarta. The study lasted for three months from September to November 2013.

Place of research conducted at the Department of Civil Engineering, State University of Jakarta. The population in this study is the student of 2009-2012 amounted to 56 people and lecturer Academic Advisory force from 2009 to 2012 amounted to 14 people so that the total respondents numbered 70 people. The method used in this study is a survey method. The trial questionnaire of 60 statements. The test is done to 10 respondents. After the test phase the results obtained valid instruments as much as 50 point statement.

Data analysis technique is done by searching percentage. The results show that: (a) Students have a negative perception about the task of the Advisory Academic faculty as mentors to students at $48,49 \%$ and the perception of the Academic Advisory lecturer on Academic Advisory duties as supervisor of students showed a positive perception of $59.58 \%$. (B) Students have positive perceptions about the task of the Academic Advisory lecturer as student advisors at $53.67 \%$ and the perception of the faculty Academic Advisory Academic Advisory duties as student advisors showed a positive perception of $54.63 \%$. (C) There is still a shortage of the Academic Advisory task that is in terms of guidance to the student schedule and record and monitor the progress of students study. Therefore there is need for improvement in this regard.
\end{abstract}

Keywords: Perception, Academic Advisory Task, Lecture 


\section{PENDAHULUAN}

Memasuki dunia perguruan tinggi berarti melibatkan diri dalam situasi hidup dan situasi akademis yang berbeda dengan apa yang pernah dialami dalam lingkungan sekolah lanjutan atas. Sebagai konsekuensinya mahasiswa wajib mengadakan adaptasi dengan dunia baru yang penuh liku-liku serta penuh risiko, terutama adaptasi pola berfikir, belajar, berkreasi, dan bertindak/beramal dalam kehidupan kampus (Salam, 2004, hal. 12). Kehidupan mahasiswa di perguruan tinggi tidak terlepas dari Tri Darma Perguruan Tinggi yaitu mendapatkan pendidikan, melakukan penelitian, dan pengabdian pada masyarakat. Penyelenggaraan pendidikan di Perguruan Tinggi sangat bertumpu pada peran dosen. Disamping dosen memiliki tugas utama mengajar, meneliti dan melaksanakan pengabdian pada masyarakat, dosen juga memiliki tugas salah satunya membimbing mahasiswa (sebagai penasehat akademik). Pada kondisi inilah, dosen harus dapat mendampingi mahasiswa dalam proses pendidikannya, sehingga mereka dapat berhasil secara memuaskan baik di bidang akademiknya maupun non akademiknya (Wahab, 2007, hal. 2). Perguruan tinggi memikul tanggung jawab dalam pembinaan mahasiswa untuk mencapai kesuksesan yakni dengan cara mendorong mahasiswa untuk melakukan kegiatan studi secara optimal, baik dalam perkuliahan dan kehidupan mahasiswa selama menjalani studi. Kenyataan menunjukkan masih banyak masalah yang dihadapi mahasiswa, diantaranya masalah yang berhubungan dengan pendidikan, masalah dalam penyesuaian diri dan hubungan sosial, masalah yang sifatnya pribadi, masalah ekonomi, masalah memilih jurusan, jabatan, dan masa depan. Kondisi tersebut mengisyaratkan bahwa bantuan pelayanan kepada mahasiswa sangat diperlukan dengan cara mengefektifkan tugas dosen sebagai penasehat akademik (Ginting, 2003, hal. 10).

Penasehat Akademik adalah staf pengajar tetap suatu perguruan tinggi yang paling tepat untuk menjadi sumber bantuan nasehat akademik agar para mahasiswa dapat menyelesaikan tugasnya sebagai mahasiswa. Penasehat Akademik bertugas untuk membantu mahasiswa dengan memberikan layanan bimbingan akademik, dimana Penasehat Akademik berperan dalam membimbing mahasiswa dalam seluruh kegiatan akademik termasuk dalam menyusun rencana studi selama di Perguruan Tinggi dan mata kuliah yang diambil pada setiap semester, dalam mengembangkan sikap yang tepat terhadap kegiatan belajar, serta dalam memecahkan persoalan yang timbul yang mungkin mempengaruhi kegiatan akademik mahasiswa (Ginting, 2003, hal. 12).

Menurut Buku Pedoman Akademik Fakultas Teknik Universitas Negeri Jakarta (2012, hal. 67), Penasehat Akademik dianjurkan mengadakan pertemuan yang terjadwal dengan mahasiswanya secara berkala, minimal satu kali dalam tiap semester. Namun kenyataannya masih banyak mahasiswa yang sama sekali tidak pernah menemui dosen Penasehat 
Akademiknya dalam satu semester. Banyak hal yang mempengaruhi, diantaranya dosen Penasehat Akademik yang tidak memberikan kepastian waktu bimbingan, persepsi kurang positif terhadap dosen Penasehat Akademik dimana mahasiswa merasa tidak perlu berkonsultasi dengan Penasehat Akademik tetapi cukup kepada kakak kelas, mahasiswa yang kurang memanfaatkan layanan bimbingan akademik yang diberikan oleh dosen Penasehat Akademik, mahasiswa yang takut bertemu dengan dosen Penasehat Akademiknya, dll.

Apabila diamati secara selintas, selama ini layanan kepenasehatan akademik lebih banyak diorientasikan kepada kegiatan, yaitu memberikan pengesahan Kartu Rencana Studi (KRS), sehingga nampak bahwa tugas yang dimainkan Penasehat Akademik selama ini lebih terfokus pada layanan adiministratif. Selain itu penggunaan Sistem Informasi Akademik (Siakad) dalam proses layanan akademik di Universitas Negeri Jakarta diduga dapat meniadakan tugas dosen sebagai Penasehat Akademik secara signifikan. Kondisi yang demikian sebenarnya tidak menguntungkan bagi proses penyelesaian pendidikan mahasiswa, karena mahasiswa tidak memperoleh pendampingan selama proses pendidikannya. Bila daya tarik eksternal sangat kuat, boleh jadi mahasiswa tidak memperoleh apa-apa dari Penasehat Akademik selama dalam proses pendidikannya. Padahal pendampingan yang intensif oleh Penasehat Akademik diharapkan mampu mengantarkan mahasiswa dalam proses pembentukan diri secara lebih terarah, sehingga pada akhirnya mahasiswa dapat menyelesaikan studi secara optimal.

Oleh karena itu, perlu dilakukan penelitian tentang "Persepsi Mahasiswa dan Dosen Penasehat Akademik tentang tugas Penasehat Akademik di Jurusan Teknik Sipil Universitas Negeri Jakarta".

\section{Pengertian Persepsi}

Persepsi adalah suatu proses yang ditempuh individu untuk mengorganisasikan dan menafsirkan kesan-kesan indera mereka agar memberikan makna bagi lingkungan mereka (Veithzal, 2003, hal. 231). Menurut Toha Miftah (2003, hal. 141) persepsi adalah suatu proses kognitif yang kompleks dan menghasilkan gambar unik tentang kenyataan yang barangkali berbeda dengan kenyataannya. Sugihartono, dkk (2007, hal.8) mengemukakan bahwa persepsi adalah kemampuan otak dalam menterjemahkan stimulus yang masuk ke dalam alat indera manusia. Jalaludin Rakhmat (2007, hal. 51) menyatakan bahwa persepsi adalah pengamatan tentang objek, peristiwa atau hubungan-hubungan yangg diperoleh dengan menyimpulkan informasi dan menafsirkan pesan.

Dari pendapat tersebut dapat disimpulkan bahwa persepsi merupakan suatu proses yang dimulai dari penglihatan hingga terbentuk tanggapan yang terjadi dalam diri individu sehingga individu sadar akan segala sesuatu dalam lingkungannya. 
Pengertian Penasehat Akademik

Penasehat Akademik adalah staf pengajar tetap suatu perguruan tinggi yang paling tepat untuk menjadi sumber bantuan nasehat akademik agar para mahasiswa dapat menyelesaikan tugasnya sebagai mahasiswa. Penasehat Akademik bertugas untuk membantu mahasiswa bimbingannya dalam seluruh kegiatan akademik termasuk dalam menyusun rencana studi selama di Perguruan Tinggi dan mata kuliah yang diambil pada setiap semester, dalam mengembangkan sikap yang tepat terhadap kegiatan belajar, serta dalam memecahkan persoalan yang timbul yang mungkin mempengaruhi kegiatan akademik mahasiswa (Ginting, 2003, hal. 12).

Menurut Buku Pedoman Akademik UNJ (2012, hal.62) Pembimbing Akademik memliki tugas sebagai berikut:

1. Membantu mahasiswa dalam menyusun rencana studi dan pengambilan mata kuliah.

2. Membantu mahasiswa mengatasi persoalan akademik yang dialami selama masa studi.

3. Mencatat perkembangan studi mahasiswa dalam buku Kontrak Mata Kuliah dan Data Kemajuan Akademik Mahasiswa.

4. Memonitor mahasiswa yang sudah atau belum mengisi KRS (termasuk penambahan mata kuliah) melalui Siakad.

5. Menyetujui ataupun menolak pengambilan mata kuliah oleh mahasiswa dengan memberikan alasan.
6. Menandatangani KRS yang telah diisi mahasiswa yang dicetak Puskom sebagai persetujuan terulis.

7. Memonitor kemajuan akademik dan perkuliahan mahasiswanya, baik melalui tatap muka atau Siakad.

8. Mengadakan pertemuan yang terjadwal dengan mahasiswa secara berkala, minimal satu kali dalam tiap semester.

9. Memeriksa daftar hasil studi menjelang penyelesaian studi mahasiswanya dan membandingkannya dengan kontrak kuliah.

Haris Karyadi (2013) mengemukakan tugas seorang mahasiswa, diantaranya :

1. Mematuhi semua peraturan yang berlaku di Universitas/Fakultas/Program Studi.

2. Ikut memelihara sarana dan prasarana serta kebersihan, ketertiban, dan keamanan Universitas/Fakultas/Program Studi.

3. Menghargai dan mengamalkan ilmu pengetahuan, teknologi, atau kesenian.

4. Menjaga kewibawaan dan nama baik Universitas/Fakultas/Program Studi.

5. Menjunjung tinggi integritas pribadinya sebagai calon sarjana yang mengutamakan nilai, moral, kebenaran, dan kejujuran.

6. Menjaga ketertiban kampus.

7. Melaksanakan tugas belajar sebaikbaiknya dan penuh tanggungjawab.

8. Berpakaian rapi dan sopan serta bersikap dan bertingkah laku santun. 


\section{METODE PENELITIAN}

Penelitian ini dilakukan di Universitas Negeri Jakarta tepatnya di Program Studi Pendidikan Teknik Bangunan Jurusan Teknik Sipil Universitas Negeri Jakarta. Waktu penelitian akan dilaksanakan pada bulan September - November 2013.

Metode penelitian adalah cara ilmiah untuk mendapatkan data dengan tujuan dan kegunaan tertentu (Sangadji, 2010, hal. 4). Metode yang digunakan dalam penelitian ini adalah metode survei dengan pengumpulan data menggunakan angket atau kuesioner. Kuesioner adalah sejumlah pertanyaan tertulis yang digunakan untuk memperoleh informasi dari responden (Arikunto, 2006, hal. 151).

Populasi permasalahan dalam penelitian ini persepsi mahasiswa dan dosen Penasehat Akademik. Adapun yang menjadi subjek penelitian adalah mahasiswa $\mathrm{S} 1$ Program Studi Pendidikan Teknik Bangunan Jurusan Teknik Sipil Universitas Negeri Jakarta angkatan 2009 - 2012 dan dosen Pembimbing Akademik Angkatan 2009 - 2012.

Sampel penelitian ini adalah mahaisiswa angkatan 2009-2012 berjumlah 56 orang dan dosen Pembimbing Akademik Angkatan 2009 - 2012 yang berjumlah 14 orang sehingga tolal seluruh sampel penelitian berjumlah 70 orang. Sampel pada penelitian ini menggunakan Simple Random Sampling.

Teknik pengumpulan data yang akan dilakukan pada penelitian ini adalah dengan kuesioner. Jenis metode kuesioner dalam penelitian ini adalah kuesioner tertutup dimana sudah disediakan jawabannya sehingga responden tinggal memilih.

Teknik analisis data pada penelitian ini menggunakan persentase dan Taksiran Uji Rata-rata $\mu$, yang dibagi menjadi dua kategori nominal ; positif dan negatif pada masingmasing indikator. Data yang telah didapat dari kuisioner berupa jawaban diberi nilai angka dan kemudian keseluruhan dibagi jumlah nilai dan dikali $100 \%$. Hasil yang telah dipersentase dimasukkan kedalam skala persepsi untuk menunjukkan hasil yang positif ataupun negatif. Adapun rumus persentase yang digunakan menurut Anas Sudijono (2010, hal.43) adalah sebagai berikut :

$$
P=f / N \times 100 \%
$$

\section{HASIL PENELITIAN}

Hasil penelitian dikelompokkan dalam dua indikator yaitu tugas Penasehat Akademik sebagai Pembimbing Mahasiswa dan Penasehat Mahasiswa

Tabel 1. Persentase Persepsi tentang Pembimbing Mahasiswa

\begin{tabular}{|c|l|c|c|}
\hline No & \multicolumn{1}{|c|}{ Sub Indikator } & Dosen & Mahasiswa \\
\hline 1 & $\begin{array}{l}\text { Membantu mahasiswa dalam menyusun rencana studi } \\
\text { dan pengambilan mata kuliah }\end{array}$ & $67,14 \%$ & $60,71 \%$ \\
\hline
\end{tabular}




\begin{tabular}{|c|l|c|c|}
\hline No & \multicolumn{1}{|c|}{ Sub Indikator } & Dosen & Mahasiswa \\
\hline 2 & $\begin{array}{l}\text { Bertanggungjawab atas kebenaran KRS mahasiswa } \\
\text { bimbingannya }\end{array}$ & $62,00 \%$ & $55,71 \%$ \\
\hline 3 & $\begin{array}{l}\text { Membantu memelihara motivasi dan semangat belajar } \\
\text { mahasiswa }\end{array}$ & $72,50 \%$ & $45,98 \%$ \\
\hline 4 & Mengatur jadwal bimbingan dengan mahasiswa & $36,67 \%$ & $31,55 \%$ \\
\hline 1 & $\begin{array}{l}\text { Membantu mahasiswa mengatasi masalah yang } \\
\text { dihadapi }\end{array}$ & $59,58 \%$ & $48,49 \%$ \\
\hline 2 & $\begin{array}{l}\text { Membantu mahasiswa mengembangkan perilaku yang } \\
\text { baik dalam perkuliahan }\end{array}$ & $52,22 \%$ & $49,80 \%$ \\
\hline 3 & $\begin{array}{l}\text { Mencatat dan memonitor perkembangan studi } \\
\text { mahasiswa }\end{array}$ & $33,33 \%$ & $45,44 \%$ \\
\hline & \multicolumn{1}{|c|}{ Skor Rata-rata } & $54,63 \%$ & $53,67 \%$ \\
\hline
\end{tabular}

Berdasarkan hasil perhitungan apabila dilihat dalam bentuk skala persepsi berdasarkan perhitungan taksiran rata - rata dengan memperbandingkan hasil perhitungan dari masing - masing nilai yang dicapai pada tiap indikator yang diambil rata- ratanya terhadap nilai maksimum yang akan dicapai. Dalam besar nilai pada skala persepsi ini bergerak secara kontinu dari 0,00 sampai 1,00 . Oleh karena data dalam skala persepsi ini bersifat dikotomis, maka orientasi persepsi dikategorikan menjadi dua kategori yakni : positif jika nilai skala persepsi diperoleh $>0,50$ dan berorientasi negatif apabila diperoleh $\leq 0,50$. Dalam hasil perhitungan keseluruhan untuk persepsi mahasiswa dan dosen Penasehat Akademik tentang tugas Penasehat Akademik diperoleh rata - rata sebesar $54,095 \%$ atau bila dibuat dalam skala persepsi sebesar 0,54095 artinya dapat dikatakan bahwa mahasiswa dan dosen Penasehat Akademik mempunyai persepsi yang positif terhadap tugas Penasehat Akademik 


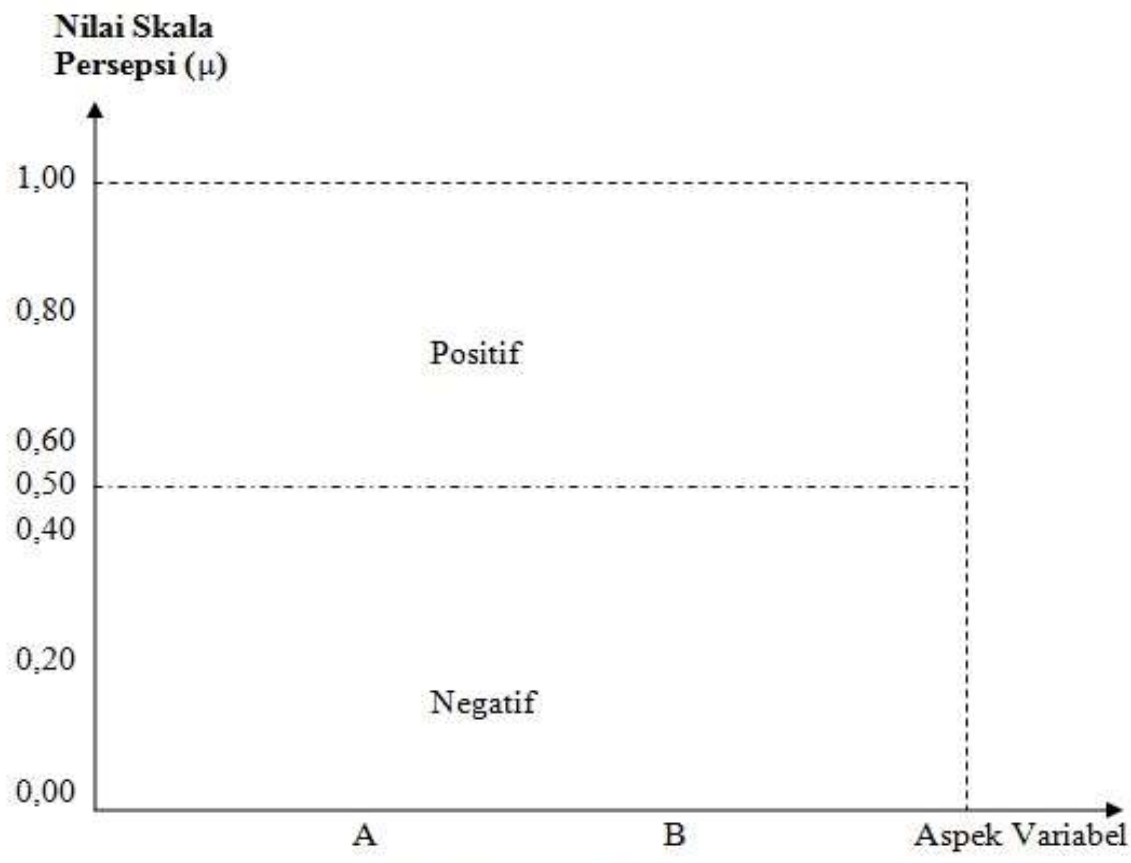

Gambar 4.3 Skala Persepsi

Keterangan Aspek variabel :
A. Pembimbing Mahasiswa
B. Penasehat Mahasiswa

Analisis hasil penelitian dalam hal pembimbing mahasiswa akan diuraikan tiap sub indikator sebagai berikut :

1. Membantu mahasiswa dalam menyusun rencana studi dan pengambilan mata kuliah

Tugas dosen Penasehat Akademik dalam hal pembimbing mahasiswa diantaranya adalah membantu mahasiswa dalam menyusun rencana studi dan pengambilan mata kuliah. Dalam hal ini dapat dilihat bahwa mahasiswa memiliki persepsi positif sebesar $60,71 \%$ begitu pula dengan dosen Penasehat Akademik sebesar $67,14 \%$.
2. Bertanggung jawab atas kebenaran KRS mahasiswa bimbingannya

Selain tugasnya membantu mahasiswa dalam menyusun rencana studi dan pengambilan mata kuliah, dosen Penasehat Akademik juga bertugas bertanggung jawab atas kebenaran KRS mahasiswa bimbingannya. Dapat dilihat hasil dari mahasiswa dan dosen Penasehat Akademik menunjukkan persepsi positif sebesar $55,71 \%$ dan $62,00 \%$. Dari hasil tersebut dapat menunjukkan bahwa selama ini tugas dosen Penasehat Akademik dalam hal bertanggung jawab atas kebenaran KRS mahasiswa bimbingannya secara keseluruhan 
sudah cukup terlaksana.

3. Membantu memelihara motivasi dan semangat belajar mahasiswa

Di samping tugasnya dalam membantu mahasiswa dalam menyusun rencana studi dan pengambilan mata kuliah, bertanggung jawab atas kebenaran KRS mahasiswa bimbingannya, dosen Penasehat Akademik bertugas membantu memelihara motivasi dan semangat belajar mahasiswa. Mahasiswa menunjukkan persepsi negatif sebesar 45,98\% sedangkan dosen Penasehat Akademik menunjukkan persepsi positif sebesar $72,50 \%$. Terdapat perbedaan yang cukup besar dari hasil tersebut, apabila dilihat lebih jauh masih terdapat aspek yang kurang yaitu diantaranya mengenai saran untuk banyak membaca literatur, motivasi untuk mengerjakan tugas, dan pemberian saran untuk memanfaatkan fasilitas internet sebagai sumber belajar.

4. Mengatur jadwal bimbingan dengan mahasiswa

Tugas dosen Penasehat Akademik sebagai pembimbing mahasiswa juga dalam hal mengatur jadwal bimbingan dengan mahasiswa. Dalam hal ini diperoleh persentase dari mahasiswa sebesar $36,67 \%$ dan dari dosen Penasehat Akademik sebesar 31,55\% dimana kedua hasil tersebut menunjukkan persepsi negatif. Keduanya merasa bahwa selama ini tugas dosen Pembimbing Akademik secara keseluruhan dalam mengatur jadwal bimbingan dengan mahasiswa masih kurang terlaksana.
Analisis hasil penelitian dalam hal penasehat mahasiswa akan diuraikan tiap sub indikator sebagai berikut :

1. Membantu mahasiswa mengatasi masalah yang dihadapi

Tugas dosen Penasehat Akademik sebagai penasehat mahasiswa diantaranya adalah membantu mahasiswa mengatasi masalah yang dihadapi. Hasil persentase yang diperoleh dari mahasiswa sebesar 49,80\% menunjukkan persepsi negatif dan persentase dari dosen Penasehat Akademik sebesar $52,22 \%$ menunjukkan persepsi positif.

2. Membantu mahasiswa mengembangkan perilaku yang baik dalam perkuliahan

Selain tugasnya membantu mahasiswa mengatasi masalah yang dihadapi, dosen Penasehat Akademik juga bertugas membantu mahasiswa mengembangkan perilaku yang baik dalam perkuliahan. Persentase yang diperoleh oleh mahasiswa dan dosen Penasehat Akademik menunjukkan persepsi positif sebesar $65,77 \%$ dan $78,33 \%$.

3. Mencatat dan memonitor perkembangan studi mahasiswa

Di samping tugasnya membantu mahasiswa mengatasi masalah yang dihadapi dan membantu mahasiswa mengembangkan perilaku yang baik dalam perkuliahan, dosen Penasehat juga memiliki tugas mencatat dan memonitor perkembangan studi mahasiswa. Hasil yang diperoleh dari mahasiswa menunjukkan persepsi negatif sebesar $33,33 \%$ 
dan hasil dari dosen Penasehat Akademik menunjukkan persepsi yang negatif pula sebesar 45,44\%. Hasil tersebut dapat menunjukkan bahwa dosen Penasehat Akademik masih kurang dalam melaksanakan tugasnya mencatat dan memonitor perkembangan studi mahasiswa.

Hasil penelitian secara keseluruhan mengenai persepsi mahasiswa dan dosen Penasehat Akademik tentang tugas Penasehat Akademik pada indikator sebagai pembimbing mahasiswa menunjukkan persepsi negatif sebesar $48,49 \%$ sedangkan dosen Penasehat Akademik menunjukkan persepsi positif sebesar $59,58 \%$. Pada indikator sebagai penasehat mahasiswa menunjukkan persepsi positif sebesar $53,67 \%$ dan hasil dari dosen Penasehat Akademik menunjukkan persepsi yang positif pula sebesar 54,63\%. Secara Keseluruhan dapat ditarik kesimpulan bahwa mahasiswa dan dosen Penasehat Akademik memiliki persepsi positif tentang tugas Penasehat Akademik Akan tetapi, masih terdapat persepsi yang negatif diantaranya yaitu mengenai mengatur jadwal bimbingan dengan mahasiswa dan mengenai mencatat dan memonitor perkembangan studi mahasiswa.

Berdasarkan hasil penelitian tindak lanjut yang dapat diberikan adalah sebagai berikut : Diperlukan adanya kerjasama yang baik antara kepala sekolah, tenaga pengajar, siswa dan pengelola teknologi informasi komunikasi sehingga pelaksanaan pembelajaran berbasis E-Learning dapat berjalan secara maksimal sehingga dapat meningkatkan prestasi belajar siswa dan diperlukan evaluasi secara rutin setiap sebulan sekali tentang pemanfaatan teknologi informasi komunikasi dalam pelaksanaan pembelajaran berbasis E-Learning di SMK Negeri 4 Jakarta.

\section{KESIMPULAN}

Berdasarkan hasil penelitian dan analisis yang telah dilakukan dapat ditarik kesimpulan sebagai berikut :

1. Mahasiswa memiliki persepsi yang negatif tentang tugas dosen Penasehat Akademik sebagai pembimbing mahasiswa. Hal ini menunjukkan bahwa selama ini dosen Penasehat Akademik belum menjalankan tugasnya dengan baik. Mahasiswa merasa dosen Penasehat Akademik belum maksimal dalam membantu mahasiswa terutama dalam hal pertemuan dengan dosen Penasehat Akademik. Persepsi negatif tersebut dapat dilihat dari perolehan persentase sebesar $48,49 \%$. Sedangkan persepsi dosen Penasehat Akademik tentang tugas Penasehat Akademik sebagai pembimbing mahasiswa menunjukkan persepsi yang positif sebesar 59,58\%. Dosen Penasehat Akademik merasa sudah cukup dalam menjalankan tugasnya sesuai dengan buku pedoman akademik Universitas Negeri Jakarta yaitu diantaranya dalam hal membantu mahasiswa menyusun rencana studi dan pengambilan mata kuliah, bertanggung jawab atas kebenaran KRS mahasiswa 
bimbingannya, dan memelihara motivasi dan semangat belajar mahasiswa.

2. Mahasiswa memiliki persepsi yang positif tentang tugas dosen Penasehat Akademik sebagai penasehat mahasiswa. Mahasiswa merasa dosen Penasehat Akademik sudah membantu mahasiswa dalam mengatasi masalah yang dihadapi. Persepsi positif tersebut dapat dilihat dari perolehan persentase sebesar $53,67 \%$. Sedangkan persepsi dosen Penasehat Akademik tentang tugas Penasehat Akademik sebagai pembimbing mahasiswa menunjukkan persepsi yang positif sebesar 54,63\%. Dosen Penasehat Akademik merasa sudah cukup dalam menjalankan tugasnya sesuai dengan buku pedoman akademik Universitas Negeri Jakarta yaitu diantaranya dalam hal membantu mahasiswa mengatasi masalah yang dihadapi dan membantu mahasiswa mengembangkan perilaku yang baik dalam perkuliahan sesuai dengan buku pedoman akademik Universitas Negeri Jakarta.

3. Masih terdapat kekurangan terhadap tugas Penasehat Akademik yaitu dalam hal mengatur jadwal bimbingan dengan mahasiswa dan mencatat dan memonitor perkembangan studi mahasiswa.

\section{Implikasi}

Hasil penelitian ini menunjukkan bahwa mahasiswa dan dosen Penasehat Akademik memiliki persepsi positif tentang tugas Penasehat Akademik di Jurusan Teknik Sipil
Universitas Negeri Jakarta. Namun pada pelaksanaan mengenai mengatur jadwal bimbingan dengan mahasiswa dan mencatat dan memonitor perkembangan studi mahasiswa masih kurang. Keadaan demikian menunjukkan bahwa perlunya meningkatkan komunikasi antara mahasiswa dan dosen Penasehat Akademik dan agar kegiatan bimbingan akademik dapat berjalan secara optimal.

Saran

Berdasarkan kesimpulan di atas, maka saran yang dapat diusulkan sebagai adalah sebagai berikut:

1. Bagi Jurusan, perlu melakukan pengawasan terhadap pelaksanaan kepenasehatan oleh dosen Penasehat Akademik. Pengawasan yang dimaksud adalah penyebaran format atau daftar isian kepada masing-masing dosen Penasehat Akademik yang dilaksanakan setiap awal semester. Dengan daftar isian tersebut diharapkan dosen penasehat akademik selalu mengetahui mahasiswa yang memiliki masalah belajar, sehingga dapat dipikirkan jalan pemecahannya dan kemajuan prestasinya dapat dimonitor.

2. Bagi Dosen Penasehat Akademik, perlu meningkatkan kualitas bimbingannya khususnya dalam hal menyediakan waktu untuk bertemu dengan mahasiswa bimbingannya minimal satu kali dalam satu semester, menginformasikan jadwal bimbingan kepada mahasiswa, serta 
mencatat dan memonitor perkembangan studi mahasiswa.

3. Bagi Mahasiswa, perlu mempertahankan komunikasi yang efektif dengan dosen Penasehat Akademik. Cara yang dapat ditempuh oleh mahasiswa agar tercapai efektivitas komunikasi dengan dosen Penasehat Akademik adalah menjalin kedekatan dengan dosen Penasehat Akademik, membangun persepsi yang positif pada dosen Penasehat Akademik, menumbuhkan keterbukaan dan kejujuran, serta membangun kepercayaan pada dosen Penasehat Akademik

\section{DAFTAR PUSTAKA}

Arikunto, Suharsimi. 2006. Prosedur Penelitian : Suatu Pendekatan Praktik. Jakarta : Rineka Cipta.

Ganda. 2004. Petunjuk Praktis Cara Mahasiswa Belajar di Perguruan Tinggi. Jakarta : Grasindo.

Ginting, Cipta. 2003. Kiat Belajar di Perguruan Tinggi. Jakarta : Grasindo.

Hidayatullah, Syaif. 2006. Pedoman Penasehat Akademik. Jakarta : UIN Syarif Hidayatullah.

Lestari, Fitri. 2003. Survei Pendapat Mahasiswa Fakultas IImu Pendidikan Universitas Negeri Jakarta Tahun Angkatan 2000/2001 Tentang Keterlaksanaan Fungsi Penasehat Akademik. Jakarta : Fakultas Teknik Universitas Negeri Jakarta.

Mulyadi. 2002. Peran dan Fungsi Dosen Penasehat Akademik STAIN Malang. Malang : STAIN.
Prayitno. 2004. Dasar-dasar Bimbingan dan Konseling. Jakarta : Rineka Cipta.

Rakhmat, Jalaludin. 2007. Psikologi Komunikasi. Bandung : Remaja Rosdakarya.

Salam. 2004. Cara Belajar yang Sukses di Perguruan Tinggi. Jakarta : Rineka Cipta.

Sangadji, Mamang. 2010. Metodologi Penelitian : Pendekatan Praktis dalam Penelitian. Jakarta : Andi.

Slameto. 2003. Proses Belajar Mengajar dalam Sistem Kredit Semester (SKS). Jakarta : Bumi Aksara.

Sudijono, Anas. 2010. Pengantar Statistik Pendidikan. Jakarta : PT RajaGrafindo Persada.

Sugihartono, dkk. 2007. Psikologi Pendidikan. Yogyakarta : UNY press

Sugiyono. 2011. Metode Penelitian Kuantitatif Kualitatif dan R\&D. Bandung : Alfabeta.

Suryadi. 1984. Universitas Terbuka Apa, Mengapa, Bagaimana. Bandung Alumni.

Suwandi, Ihsan. 1997. Peranan dan Fungsi Penasehat Akademik, Makalah Pelatihan Dosen Penasehat Akademik IKIP Malang.

Toha, Miftah. 2003. Perilaku Organisasi Konsep Dasar dan Aplikasinya. Jakarta : PT Raja Grafindo Persada.

UNJ. 2012. Pedoman Akademik Fakultas Teknik (FT). Jakarta : UNJ

Veithzal, Rifai. 2003. Kepemimpinan dan Perilaku Organisasi. Jakarta : PT Raja Grafindo Persada.

Walgito, Bimo. Pengantar Psikologi Umum. Yogyakarta : Andi 
Wahab, Rochmat. 2007. Meningkatkan Efektivitas Kepenasehatan Akademik. Yogyakarta : UNY staff
Karyadi, Haris. 2013. Hak dan Kewajiban Mahasiswa. http//groups.google.com (diakses 16 Januari 2014). 